\title{
Needs Analysis: An Effective Way in Business English Curriculum Design
}

\author{
Juan Li \\ School of Foreign Language Studies, Shandong Jiaotong University, Jinan, China
}

\begin{abstract}
As one of the most important branches of ESP (English for Specific Purposes), Business English has nearly sixty years' history in China. Needs analysis is the most important stage of ESP teaching and is a widely used tool to study the validity and relevancy of all curriculum design activities in Business English teaching. It assures a flexible curriculum responsive to the needs of various stakeholders of education. Under the guidance of Needs Analysis Theory, this paper aims to discuss whether and how needs analysis can be implemented in Business English curriculum design and the results may shed light on the improvement of the Business English teaching.
\end{abstract}

Index Terms — need analysis, Business English, curriculum design

\section{INTRODUCTION}

China's growth is felt in nearly every corner of the globe. The prosperous of business have been a great driving force for the development of Business English and the demand for Business English grows dramatically. Even though Business English teaching has become popular, for years the instruction has been limited to an approach which fundamentally focuses on the drill of language skills and ignores the social needs and learners' personal interests. This often leads to students' low motivation in Business English study and their poor performance of language use in their future profession. However, due to the influence of traditional teaching opinions and limited knowledge of needs analysis theories, course designers and language teachers in China either neglect needs analysis or cannot carry out it effectively. As a result, Business English teaching in colleges and universities is facing many challenges including optimizing course design, setting teaching goals, updating teaching concepts, training teachers and compiling textbooks. Based on needs analysis theory, this assay discusses Business English, need analysis theory and the ways of how to apply need analysis into the curriculum design of Business English courses.

\section{NeEd ANALYsis AND ITS Models}

\section{A. Need Analysis}

Needs analysis has existed in the world of language education for two or three decades. The role of needs analysis in any ESP course is invaluable. It is considered as a prerequisite in any course design (Richterich and Chancerel, 1987). "It is also considered as one of the key stages in ESP, the others being the syllabus design, selection and production of materials, teaching and learning, and evaluation." (Dudley-Evans and St John, 1998, p 125). Johns (1991) also regards needs analysis as the first step in curriculum design for it can provide validity and relevancy for all the follow-up curriculum design activities. Needs analysis refers to the activities involved in gathering information that will serve as the basis for developing a curriculum that will meet the learning needs of a particular group of learners. Once identified, needs can serve as the basis for designing tests, compiling materials, designing teaching activities, and evaluating strategies, as well as for reevaluating the precision and accuracy of the original needs analysis. It is regarded as an indivisible part of systematic curriculum design. (Brown, 2001). Nunan (1994, p 54) argues that "needs analysis is a set of procedures for specifying the parameters of a course of study. Such parameters include the criteria and rationale for grouping learners, the selection and sequencing of course content, methodology, course length, and intensity and duration."

\section{B. Models of Need Analysis}

Scholars have put forward various models of needs analyses. However, the four models of needs analysis are gaining much recognition by researchers, each model can identify language needs from different perspectives.

\section{Target Situation Analysis (TSA)}

Target situation is the situation in which the language learners will be using the language they are learning (Hutchinson \& Waters, 1987). Target Situation Analysis (TSA) is a kind of needs analysis which mainly focuses on students' needs at the end of a language course (Robinson, 1991). The "target needs" are the "product" of a target situation analysis. The identification of the target situation is a prerequisite for the Business English course designers. Then a rigorous analysis of the linguistic features of the designated situation should be carried out. The identified features, accordingly, will form the syllabus of the Business English course. The information collected in the target 
situation includes the language application information, communicative skills, and the cognition of the teaching objectives of the learners, working institutions and societies.

It is commonly agreed by all ESP practitioners that Munby is the first specialist who have the systematic and influential ideas about target situation analysis. He formulated the famous "Communication Needs Processor (CNP)", which consists of a range of questions about key communication variables (topic, participants, medium, etc.) (Munby, 1978). These variables can be used to identify the target language needs of any group of learners (Hutchinson and Waters, 1987). As Coleman (1988, p105) illustrates: "Probably the most influential of all needs analysis procedures currently available is Munby's "communication needs processor". The most useful feature of Munby's model is its comprehensive data banks, for example: the micro-skills and attitudes, which can be used as checklists for the resultant syllabus. The instrument he proposed is supposed to enable the needs analyst to draw up an accurate profile of an individual language learner.

There are two stages involved in Munby's Model of Need Analysis: Communication Need Processor(CNP) and the profile of needs which is derived from the CNP in terms of micro-skills and micro-functions. The CNP is set out under eight variables, namely the purposive domain, setting, interaction, instrumentality, dialect, target level, communicative event, and communicative key, which are organized as parameters and are dynamically related with each other. The operation of CNP begins with the processing of its "inputs", the information regarding the identity and language of the foreign language participants. Then the information of the eight variables are required. In the second stage of the model, the user must take the activities with their communicative keys and decide which of three alternative ways of processing them is appropriate. "The alternatives are: (i) specification of syllabus content by focusing on micro-skills. (ii) specification by focusing on micro-functions (iii) specification by focusing on linguistic forms.Munby explored thoroughly every aspect relating to learner's needs"(Munby, 1978, p95). Munby thinks of the unthinkable and is very thoughtful in his work. His work proves to be the most detailed,complex and informative and is illustrated by Zhao(2005) as follows:

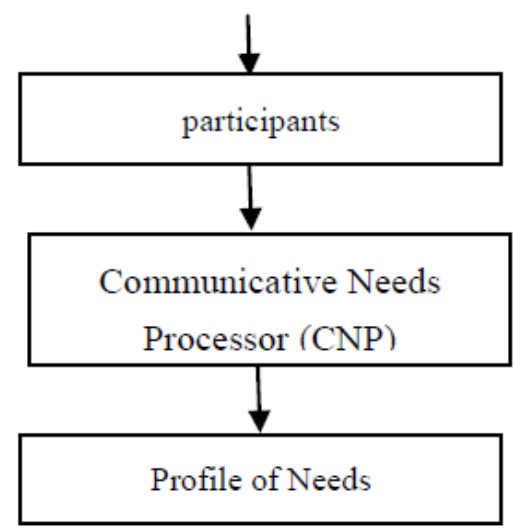

Figure 1 .John Munby's Model of Needs Analysis (Zhao, 2005)

\section{Present Situation Analysis (PSA)}

While Target Situation Analysis deals with the analysis of learner's targets, without which it is difficult to design a syllabus to achieve them. Present Situation Analysis (PSA), on the other hand, analyses learner's present situation and shows the gap between the present and the target. When emphasizing the learner's motivations in the process of studying, the needs that the students'self-perception about learning cannot be neglected. PSA exlpores to find out the language proficiency of the students when the language course begins and their strengths and weakness (Robinson, 1991). Three basic sources of information are suggested by Richterich and Chancerel in 1980: the information about the students themselves, the language-teaching organizations and the user-institution. This is in accordance with Jordan's (1997) opinion: the sources of information in the needs analysis are: the students themselves, the academic institution and the prospective employer. Hutchinson \& Waters (2002) gave some examples and states that no necessary relationship are showed between what the learners want or feel they need and the necessities, which are perceived by the sponsor or ESP teachers. Richard Mead's (as cited in Hutchinson \& Waters, 1980) carried out a research about the motivation of students following ESP courses, he found that sometimes the needs perceived by the teacher may conflict with the students' needs and thus produce a de-motivating effect.

Bloor (1984) maintained that a needs analysis may be "target-centered" or "learner-centered". A target-centered need analysis focus the learners' future role in the target situation and seeks to specify the language skills and linguistic knowledge the learner need to know. A leaner-centered need analysis, on the other hand, emphasis what the learner "can do" at the beginning og the course and the problems the learner may encounter during the learning process. The "target-centered analysis" and "the learner-centered analysis" named by Bloor are the counterparts of TSA and PSA. Bloor further pointed out that in order to specify an adequate teaching syllabus, it is almost certainly desirable to operate both "target-centered" and "learner-centered" needs analysis.

\section{Hutchinson and Waters' Model}


Hutchinson and Waters (1987) first put forward the learning-Centered Approach needs analysis model. In the model, needs analysis consists of two parts: target situation needs and learning needs. Target needs include "necessities", "lacks" and "wants". "Necessities" are determined by the demand of the target situation. They are the necessary needs that enable the learner to use effectively in the target situation. "Lacks" are the gap between "necessities" and what the learner already knows, that is the existing proficiency of the learners. "Wants" are learners' subjective needs, which has no direct relationship between the objective needs perceived by the teachers and course designers. Learning needs, on the other hand, are how learners learn the language.

Learning needs are about the learners' motivation of learning the language, the way they prefer to learn, the available resources, the time and place the course will take place and the learners' personal information. Hutchinson and Waters compare the Business English course to a journey (Figure 2). The starting point of the journey is the "lacks" and the destination is the "necessities". Learning needs are how are the learners get from the starting point to the destination. Sometimes the "destination" may be deviated because the "necessities" perceived by the sponsors may be different from what the learners want or feel they need.

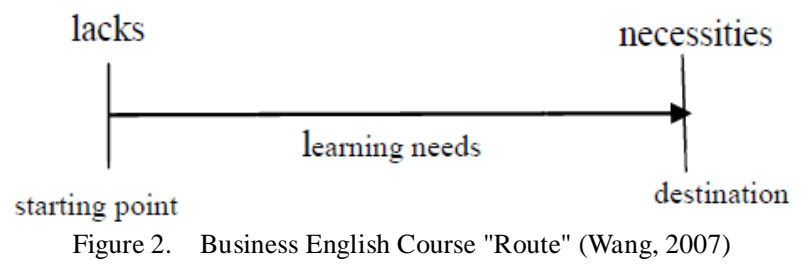

\section{Dudley-Evans and St John's Model of Needs Analysis}

Dudley-Evans \& St John (1998) and Dudley-Evans (1998) established a model for Business English courses which contain the following aspects illustrated in the figure:

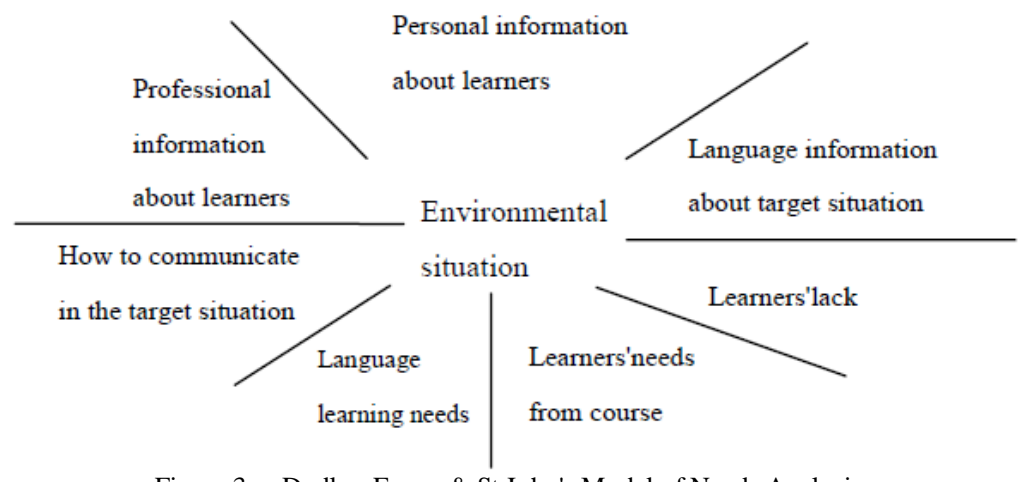

Figure 3. Dudley-Evans \& St John's Model of Needs Analysis

In the model, professional information are the tasks and activities in which learners are using or will be using English for, this is the Target Situation Analysis and objective needs of the learners; while personal information concerns about the factors that might affect the way when learners learn, such as their previous learning experiences, cultural background, attitude to English, or even their reasons and expectations for taking the course, this can be called as the learners' subjective needs, which includes learners' wants, means and strategies. The English language information about the learners' is their current skills and language uses, this part belongs to the Present Situation Analysis and this is the effective way to assess the learners' lack, which is the gap between "the English language information about the learner's" and "professional information about the learners". The main concern of the Present Situation Analysis is the current language proficiency of the learners. Learning needs Analysis seeks to find out the effective ways of learning the language and skills of the lacks. Professional communication information concerns the how the language and skills are uses in the target situation.

With the progress of the course, the attitudes and approach of students may change accordingly. Need analysis, therefore, is recommended to be conducted during the whole process of the course. (Richterich and Chancerel, 1987; Robinson, 1991) Moreover, need analysis can be carried out at different stages during the curriculum design process and the identification and analysis of needs should be a continuous process (Richterich and Chancerel, 1987; Knox, 1987). This is helpful to both the course designers and teachers to make necessary changes. Moreover, need analysis can take many forms, whatever the forms is, the basic purpose should be the to find the wants and needs of learners. If the teaching approaches and teaching contents match the determined needs, the learners' motivation will be enhanced.

\section{ESP \& BUSINESS ENGLISH}

The definitions of ESP (English for Specific Purposes) as conceptual term appeared in the literature only in the 1960s. 
Halliday, Mcinfash and Strevens first put forward the definition of ESP: "English for civil servants; for policemen; for officials of the law; for dispensers and nurses; for specialists in agriculture; for engineers and fitters." (1964) . Currently, the most frequently cited ESP book may be Hutchinson and Waters' English for Specific Purposes, in which they hold the opinion that "ESP is an approach to language teaching in which all decisions as to content and method are based on the learner's reason for learning."(Hutchinson and Waters, 1987, p.19). According to them, ESP is defined as an "approach" rather than a product, and ESP does not involve a particular type of language, teaching materials or methodology.

Business English had been discussed in the western world in the late 1960s and early 1970s, but in China, it is only after the opening up to the outside world that Business English had aroused the attention of the domestic researchers. Up to now, there exist three major perspectives to define Business English.

(1) Business is a variety of ESP.

(2) Business English is a social functional variety of English.

(3) Business English is viewed as a major or discipline.

Chinese researchers and researchers abroad have reached a common view that Business English is a variety of ESP . Owing to the increasing growth of international business and globalization, Business English has become a major expansion of ESP. In China, Business English is viewed as a major or discipline, the best example may be the fact that over 30 universities and colleges were approved by the Ministry of Education to set up Business English Major since 2007. Different from the practice in other countries where ESP(including Business English) are considered as teaching systems or profession, Business English is seen as a major or discipline in China. Chinese researchers spend efforts on the scientific research of the way how to cultivate the talents. So it is recognized in China that discipline, major become the proper perspective to learn Business English. According to Hutchinson \& Waters, what distinguishes the ESP learners from the learners of General English is need analysis, which is the irreducible minimum of an ESP approach to course design. The study of Business English should follow the framework of ESP. This thesis will regard Business English as a major by using the approaches of ESP.

\section{Application of NeEd Analysis into Business English Curriculum Design}

Need analysis must be reliable, efficient and usable. Need analysis can be conducted through three steps: plan, information collection and information analysis. Plan is of great importance to effective need analysis. Before the research, designers should make it clear the following questions:

(1) What kind of information is needed?

(2) Why the information is needed?

(3) How to acquire the information?

After answering the above three questions, the next step would be to design the research questions according to these questions. When the plan is made and the questions are designed, the information can be collected. When applying the need analysis theory into the Business English curriculum design, course designers should study the needs of learners, society and the school.

\section{A. The Analysis of the Present Situation}

As has mentioned above, the three basic sources of information is the students, and language-teaching establishment and the user-institution. During this information collecting process, a lot of information should be collected: the learners' learning background, their concept of teaching and learning and their preferred methodology and techniques, their wants, either objective or subject, and the resources available etc. For a Business English student who is studying at a university, the courses are compulsory and their attitude toward the Business English courses varies. There are relatively large number of professional teachers, whose knowledge of and attitude to the subject content varies a great deal. The attitudes of the students and the teachers should be investigated and determined accordingly. The learning materials are available and students can get aids from various sources. On the other hand, the course designers are usually the Business English teachers, it is comparatively easier for them to collect information from the students and the teaching institutions. When doing present situation analysis, learners' subjective need, objective needs, learning needs, learning motivation and language proficiency should be considered. If the present situation is finished, all the parties involved will benefit from a proper analysis of the present situation and this will pave the way for the final accomplishment of curriculum design.

\section{B. The Analysis of the Target Needs}

Target needs are determined by the needs of the target situation. The target needs analysis is in fact a matter of asking information about the target situation and the learners' attitudes of that situation. These questions are about the reason why the language is used, the way the language is used, the content areas of the courses, the relationship between the learners and the time and place where language will be used.

For Business English students, their motivation of learning English might be to work in a business-related institution. It is advisable for the course designers to analysis the needs of the employer's anticipation and demand. The language learned by a Business English student might be to understand business emails, to talk via telephone, to communicate 
effectively at an trade fair and so on. During the learning process, the corresponding language skills should be highlighted. When doing this, questionnaires, interviews, observations, case studies can be used to inquire the target need. If necessary, some other ways may be used to acquire the complete and accurate information.

What should be noted is, when the curriculum design is done, the curriculum designers should again solicit views from foreign trade companies, joint ventures, foreign department of banks, foreign insurance companies and other companies where the Business English students work to re-evaluate the curriculum and further better the curriculum.

\section{The Analysis of Localized Features}

The goal of the Business English teaching is to cultivate interdisciplinary talents. Owing to the different features of different provinces, districts and schools, such as the regional economic development levels, the developing level of disciplines in different schools, the guiding ideology for university management and the school-running characteristics, the content of courses, teaching mode, training objective and standard, are not estimated to be the same. It is suggested that needs analysis should be established not only on the basis of target needs and learning needs, the district features, suggestion from experts, school-running orientation and features, guidelines for running universities, should be also be considered. Examples like the main subjects in financial universities may be international finance or international payment; while in marine universities, the courses such as international shipping, international logistics should be emphasized. As is famous for large number of "student bosses", Yiwu Industrial and Commercial College may set its main courses as "E-business or international logistics" based on Yiwu's local characteristics.

\section{Procedures of Needs Analysis}

When conducting need analysis, a variety of procedures can be used and the type of procedures selected determines the information acquired. (Richards, 2002). Schutz and Derwing (1981), offered eight elaborative steps to conduct a needs assessment. These steps are: to define purpose, to delimit target population, to delimit parameters of investigation, to select information gather instrument, to collect data, to analyze results, to interpret results, and to critique the project.

(1) Defining the purpose involves identifying the goals of the study precisely in order to achieve useful results.

(2) Delimiting the target population refers to defining the target population of the study in order to make practical decisions about monetary, position and time considerations.

(3) Delimiting the parameters of investigation includes the planning of the limitations of the study in order to raise its effectiveness.

(4) Selecting the information gathering instrument refers to choosing the appropriate data collection instruments. Selecting the information gathering instruments depends on the conditions, scope and objectives of the study.

(5) The collection of the data is directly related to the data collection instruments that will be used in this process. Different types of data gathering instruments, such as distributing questionnaires, conducting interviews, or doing observations require different processes to follow up.

(6) Analyzing the results, the researcher may benefit either from computer-assisted analysis techniques or the observations and interpretations. Using computer-assisted analysis techniques to analyze data is more reasonable for the sake of time and effort, compared with observations and interpretations that require extended contact with the target situations and qualitative interpretations of the data.

(7) In the interpretation of the results section, the researcher explores what s/he had derived from the process of data interpretation. There, the researcher attempts to draw implications about the learners' language needs by using the data analysis results.

(8) Finally, the critique of the project section includes drawing out implications for further studies and explains the limitations of the study.

\section{CONCLUSION}

Curriculum design is a process, during which the basic principle of a teaching plan is been conveyed, supervised and put into practice. Needs analysis is the premise of the other phases. A well-established curriculum design should first have a thorough investigation of the needs of learners, teaching organization and the society. As one of the most important branch of ESP, Business English is developing at an unprecedented speed. Over 1000 universities and colleges have Business English courses to help English majors or Business English majors to meet the competition in future career. In order to cultivate multi-discipline Business English talents and offer better Business English courses, it is necessary to take need analysis theory as a guideline the put the needs of various stakeholders into consideration when designing Business English curriculum. Need analysis is no doubt an effective way for the Business English curriculum design.

\section{ACKNOWLEDGMENT}

This work is supported by the Research Base of Humanities and Social Sciences of Shandong Province-International Business Study Center, the Teaching Research Foundation of Shandong Jiaotong University: Curriculum Design for Business English Students Based on Needs Analysis Theory-A Case Study of Shandong Jiaotong University (No. JY201211), and the Scientific Research Foundation of Shandong Jiaotong University: "Cultural Capital"and Culture 
Teaching-A Probe to the Culture Teaching in Teaching of Chinese as a Foreign Language Based on Pierre Bourdieu's Cultural Theory.

\section{REFERENCES}

[1] Bloor, M. (1984). Identifying the components of a language syllabus: A problem for designers of courses in ESP or communication studies. In R. Williams, J. Swales, \& J. Kirkman (Eds.), Common ground - shared interests in ESP and communication studies (ELT Documents 117, pp. 15-24). Oxford: Pergamon Press.

[2] Brown, J. D. (2001). Using surveys in language programs. Cambridge: Cambridge University Press.

[3] Coleman, H. (1988). Analysis language needs in large organization. English For Specific Purposes, vol. 7, 3, pp.155-169

[4] Dudley-Evans, T., \& St. John, M.J. (1998). Developments in ESP: a multi-disciplinary approach. Cambridge: Cambridge University Press

[5] Halliday, M.A.K., McIntosh, A. \& Strevens, P. (1964). The linguistic Sciences and Language Teaching. London: Longman.

[6] Hutchinson, T., \& Waters, A. (1987). English for Specific Purposes. Cambridge: Cambridge University Press.

[7] Johns, A. (1991). English for specific purposes: its history and contribution. In Celce-Murcia, M. (Ed). Teaching English as a second or foreign language (pp.67-77). Boston, MA: Heinle \& Heinle.

[8] Li, Juan. (2011). Curriculum Design for Business English Students Based on Needs Analysis Theory-A Case Study of Shandong Jiaotong University. Unpublished master's thesis, Shandong Normal University, Jinan.

[9] Munby, J. (1978). Communicative Syllabus Design. Cambridge: Cambridge University Press.

[10] Nunan, D. (1994). The learner-centered curriculum. Cambridge: Cambridge University Press.

[11] Richterich R. \& Chancerel L. (1980). Identifying the needs of adults learning foreign language, Oxford: Pergamon Press for the Council of Europe.

[12] Richterich, R. \& J.J. Chancerel. (1987). Identifying the needs of adults learning a foreign language. Oxford: Prentice Hall.

[13] Robinson, P. (1991).ESP Today: A Practitioner's Guide. Hemel Hempstead: Prentice Hall.

[14] Schutz, N. W. \& Derwing, B.L. (1981). The problems of needs assessment in English for specific purposes: Some theoretical and practical considerations. In R. Mackay \& J.D. Palmer (Eds.), Language for specific purposes program design and evaluation (pp.29-45). Rowley, MA: Newbury House.

[15] Wang, X.X. (2007). An analysis of English Majors' needs in BE course design. Unpublished master's thesis, Northeast University, Changchun.

[16] Zhao, Z. C. (2005). Needs Analysis and Curriculum Design -A Tentative Research on the ESP Courses of Non-English Postgraduates. Unpublished master's thesis, Dalian University of Technology, Dalian.

Juan Li, born in Bayannaoer, China in 1980. She received her M.A in curriculum and pedagogy (English) in Shandong Normal University. She is currently a lecturer in the School of Foreign Languages, Shandong Jiaotong University, Jinan, China. Her research interests include Business English teaching and cross-cultural communication. 